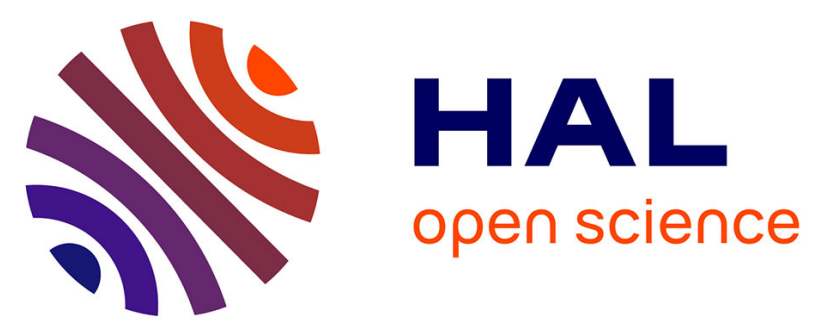

\title{
Should we treat mild hypotension in septic patients in the absence of peripheral tissue hypoperfusion?
}

Jean-Rémi Lavillegrand, Guillaume Dumas, Naïke Bigé, Daniel Zafimahazo, Bertrand Guidet, Eric Maury, Hafid Ait-Oufella

\section{To cite this version:}

Jean-Rémi Lavillegrand, Guillaume Dumas, Naïke Bigé, Daniel Zafimahazo, Bertrand Guidet, et al.. Should we treat mild hypotension in septic patients in the absence of peripheral tissue hypoperfusion?. Intensive Care Medicine, 2018, 44 (9), pp.1593-1594. 10.1007/s00134-018-5315-5 . hal-01958921

\section{HAL Id: hal-01958921 \\ https://hal.sorbonne-universite.fr/hal-01958921}

Submitted on 18 Dec 2018

HAL is a multi-disciplinary open access archive for the deposit and dissemination of scientific research documents, whether they are published or not. The documents may come from teaching and research institutions in France or abroad, or from public or private research centers.
L'archive ouverte pluridisciplinaire HAL, est destinée au dépôt et à la diffusion de documents scientifiques de niveau recherche, publiés ou non, émanant des établissements d'enseignement et de recherche français ou étrangers, des laboratoires publics ou privés. 


\title{
Should we treat mild hypotension in septic patients in the absence of peripheral tissue hypoperfusion?
}

\author{
Jean-Rémi Lavillegrand', Guillaume Dumas ${ }^{1}$, Naïke Bigé1 , Daniel Zafimahazo' ${ }^{1}$, Bertrand Guidet ${ }^{1,2,3}$, \\ Eric Maury ${ }^{1,2,3}$ and Hafid Ait-Oufella ${ }^{1,2,4^{*}}$ (1)
}

Dear Editor,

In sepsis patients, international guidelines recommend to maintain a mean arterial blood pressure higher than $65 \mathrm{mmHg}$ and in hypertensive patients higher than $75 \mathrm{mmHg}$ [1]. In a recent issue of Intensive Care Medicine, Maheshwari et al. retrospectively analyzed a large database in the USA and reported that both mortality and acute kidney failure increased when mean arterial blood pressure (MAP) decreased [2]. The evidence for clearly defining mean blood targets to optimize tissue perfusion in septic patients remains controversial. During the last two decades, several groups have reported the strong predictive value of microcirculatory disorders and tissue hypoperfusion in septic shock patients [3]. Furthermore, variable impact of arterial hypotension on microcirculatory blood flow and tissue perfusion has been reported [4]. Indeed, in sepsis patients with comparable MAP, tissue perfusion could be altered or preserved, suggesting that a "universal MAP target" is probably not the right direction [5]. We believe that tissue perfusion analysis could be helpful to guide MAP target. Here, we report that mild arterial hypotension could be tolerated in septic patients in the absence of tissue hypoperfusion.

We conducted a retrospective observational study in our 18-bed ICU in a tertiary teaching hospital. All consecutive patients older than 18 years admitted for sepsis and MAP lower than $65 \mathrm{mmHg}$ at admission were

\footnotetext{
*Correspondence: hafid.aitoufella@aphp.fr

${ }^{1}$ Assistance Publique-Hôpitaux de Paris (AP-HP), Hôpital Saint-Antoine, Service de Réanimation Médicale, 184 rue du Faubourg Saint-Antoine, Cedex 12, 75571 Paris, France

Full author information is available at the end of the article
}

included from January to December 2017. In total 124 septic patients were included during a 1-year period. Median SAPS II was 51 [40-70] and median age was 68 [58-81] years. The most frequent primary sites of infection were the lungs $(23 \%)$ and the urinary tract $(19 \%)$. After initial resuscitation including infection source control, antibiotic administration, and fluid infusion, MAP reached $65 \mathrm{mmHg}$ in 24 patients but remained below this threshold in 100 patients. Next, norepinephrine was infused in 89 patients to maintain MAP higher than $65 \mathrm{mmHg}$ but mild arterial hypotension was permitted in 11 patients because of the absence of peripheral hypoperfusion (Supplemental Table 1). MAP was below $65 \mathrm{mmHg}$ after initial resuscitation but was higher than $50 \mathrm{mmHg}$ (Supplemental Fig. 1). Despite mild hypotension, no mottling, no oliguria, and no consciousness impairment were observed, suggesting that the brain, kidney, and skin perfusions were preserved. Combining daily clinical evaluation, ECG, and troponin measurements, we did not detect myocardial ischemia during ICU stay. As described in Table 1, peripheral tissue perfusion was maintained over time; arterial hypotension and hyperlactatemia recovered within $24 \mathrm{~h}$, and all patients were discharged alive from ICU. Only one patient with end-stage renal disease underwent one hemodialysis session.

Our results suggest that a mild arterial hypotension could be tolerated in septic patients in the absence of tissue hypoperfusion. However, this observation has to be analyzed with caution because severity (SAPS II and percentage of patients under mechanical ventilation) is lower in the permissive hypotension group when compared to the septic group receiving vasopressors to maintain 
Table 1 Description of clinical and biological parameters over time following initial resuscitation (H0) in the group of patients with permissive mild arterial hypotension

\begin{tabular}{|c|c|c|c|c|c|}
\hline Variables & HO & H6 & $\mathrm{H} 12$ & $\mathrm{H} 18$ & $\mathrm{H} 24$ \\
\hline Glasgow & $15[15-15]$ & $15[15-15]$ & $15[15-15]$ & $15[15-15]$ & $15[15-15]$ \\
\hline Heart rate $\left(\mathrm{min}^{-1}\right)$ & 104 [92-106] & 90 [79-119] & 93 [85-109] & 89 [82-98] & $94[75-110]$ \\
\hline $\mathrm{DAP}(\mathrm{mmHg})$ & 49 [44-53] & $49[44-52]$ & $50[48-53]$ & $54[50-57]$ & $59[56-63]$ \\
\hline MAP (mmHg) & $62[57-62]$ & $60[57-63]$ & $62[60-64]$ & 67 [59-69] & 73 [69-76] \\
\hline Diuresis $(\mathrm{mL} / \mathrm{kg} / 6 \mathrm{~h})$ & - & $6.9[5.4-8.5]$ & $7[5.1-8.5]$ & $7.3[4.7-8]$ & $6.9[4.3-9.9]$ \\
\hline Mottling score & $0[0-1]$ & $0[0-0]$ & $0[0-0]$ & $0[0-0]$ & $0[0-0]$ \\
\hline Lactate arterial level ( $\mathrm{mmol} / \mathrm{L})$ & $1.8[1.2-3.1]$ & - & $1.1[0.9-1.2]$ & - & $1.1[1.0-1.3]$ \\
\hline SOFA score & $4[3-6]$ & - & - & - & $2[1-4]$ \\
\hline
\end{tabular}

Data are expressed as median [IQRs]

$D A P$ diastolic arterial pressure, MAP mean arterial pressure, SOFA sequential organ failure assessment

a MAP higher than $65 \mathrm{mmHg}$. In addition, the primary site of the infection was different between groups with no lung infection and a majority of urinary tract infections in the permissive hypotension group. Such personalized management requires ICU admission and close monitoring but could limit the use of invasive devices and norepinephrine, both having potential side effects.

\section{Electronic supplementary material}

The online version of this article (https://doi.org/10.1007/s00134-018-5315-5) contains supplementary material, which is available to authorized users.

\section{Author details}

${ }^{1}$ Assistance Publique-Hôpitaux de Paris (AP-HP), Hôpital Saint-Antoine, Service de Réanimation Médicale, 184 rue du Faubourg Saint-Antoine, Cedex 12, 75571 Paris, France. ${ }^{2}$ Université Pierre et Marie Curie-Paris 6, Paris, France. ${ }^{3}$ Inserm U1136, 75012 Paris, France. ${ }^{4}$ Inserm U970, Centre de Recherche Cardiovasculaire de Paris (PARCC), Paris, France.

\section{Author contributions}

Study concept and design, all authors. Acquisition of data, JRL, GD, NB, DZ, and HAO. Drafting of the manuscript, HAO, EM, and BG. Critical revision of manuscript, all authors. Statistical analysis, JRL and HAO.

\section{Funding}

None.

\section{Compliance with ethical standards}

\section{Conflicts of interest}

The authors declare that they have no competing interest.

\section{References}

1. Rhodes A, Evans LE, Alhazzani W, Levy MM, Antonelli M, Ferrer R, Kumar A, Sevransky JE, Sprung CL, Nunnally ME, Rochwerg B, Rubenfeld GD, Angus DC, Annane D, Beale RJ, Bellinghan GJ, Bernard GR, Chiche JD, Coopersmith C, De Backer DP, French CJ, Fujishima S, Gerlach H, Hidalgo JL, Hollenberg SM, Jones AE, Karnad DR, Kleinpell RM, Koh Y, Lisboa TC, Machado FR, Marini JJ, Marshall JC, Mazuski JE, McIntyre LA, McLean AS, Mehta S, Moreno RP, Myburgh J, Navalesi P, Nishida O, Osborn TM, Perner A, Plunkett CM, Ranieri M, Schorr CA, Seckel MA, Seymour CW, Shieh L, Shukri KA, Simpson SQ, Singer M, Thompson BT, Townsend SR, Van der Poll T, Vincent JL, Wiersinga WJ, Zimmerman JL, Dellinger RP (2017) Surviving Sepsis Campaign: international guidelines for management of sepsis and septic shock: 2016. Intensive Care Med 43(3):304-377. https:// doi.org/10.1007/s00134-017-4683-6

2. Maheshwari K, Nathanson BH, Munson SH, Khangulov V, Stevens M, Badani H, Khanna AK, Sessler DI (2018) The relationship between ICU hypotension and in-hospital mortality and morbidity in septic patients. Intensive Care Med. https://doi.org/10.1007/s00134-018-5218-5

3. Ait-Oufella H, Bakker J (2016) Understanding clinical signs of poor tissue perfusion during septic shock. Intensive Care Med 42(12):2070-2072. https://doi.org/10.1007/s00134-016-4250-6

4. Ince C (2005) The microcirculation is the motor of sepsis. Crit Care 9(Suppl 4):S13-S19

5. Dunser MW, Takala J, Brunauer A, Bakker J (2013) Re-thinking resuscitation: leaving blood pressure cosmetics behind and moving forward to permissive hypotension and a tissue perfusion-based approach. Crit Care 17(5):326. https://doi.org/10.1186/cc12727 